\title{
Effect of injection of gonadotrophin-releasing hormone on testicular steroidogenesis in the hypogonadal (hpg) mouse
}

\author{
J. W. Sheffield and P. J. O'Shaughnessy \\ Department of Veterinary Basic Sciences, Royal Veterinary College, Royal College Street, \\ London NWI OTU, UK
}

\begin{abstract}
Summary. Hypogonadal ( $h p g$ ) mice were injected once daily with $10 \mathrm{ng}, 50 \mathrm{ng}$ or $1 \mu \mathrm{g}$ GnRH for 5,10 or 20 days or 12 times daily with $4.2 \mathrm{ng} \mathrm{GnRH}$ for 5 days. Basal and hCGstimulated production in vitro of androstenedione, testosterone and $5 \alpha$-androstane$3 \alpha, 17 \beta$-diol (androstanediol) were measured by radioimmunoassay. All doses of GnRH increased testicular weight and in-vitro androgen production although seminal vesicle weights were unchanged and serum testosterone concentrations remained undetectable. After 5 days' treatment androstenedione and androstanediol were the dominant androgens produced, the latter indicating the presence of high levels of $5 \alpha$-reductase. By 20 days testosterone production was predominant after treatment with higher doses of GnRH. Total androgen production (androstenedione + testosterone + androstanediol) after 5 and 10 days was similar at all concentrations of GnRH used. After 20 days' treatment total androgen production was significantly greater with $50 \mathrm{ng}$ $\mathrm{GnRH} /$ day than with 10 or $1000 \mathrm{ng}$ /day. Multiple daily injections of $4 \cdot 2 \mathrm{ng} \mathrm{GnRH}$ (total dose $50 \mathrm{ng} /$ day) had no greater effect on androgen production in vitro compared to single daily injections of $50 \mathrm{ng}$. This suggests that under the conditions used in this study the testis does not require pulsatile release of the gonadotrophins. The pattern of $\left[{ }^{3} \mathrm{H}\right]$ pregnenolone metabolism was measured after 5 days injection of $50 \mathrm{ng} \mathrm{GnRH} /$ day. Compared to control hpg animals there was a significant increase in formation of $\mathrm{C}_{19}$ steroids, synthesis being solely through the 4-ene pathway. These results show that GnRH treatment of $h p g$ mice will induce testicular steroidogenesis. The changes which occur after GnRH treatment show similarities to those in the normal animal around puberty.
\end{abstract}

Keywords: hypogonadal; testis; GnRH; androgen; mouse

\section{Introduction}

The hypogonadal ( $h p g$ ) mouse contains a deletion in the gene encoding for gonadotrophinreleasing hormone (GnRH) (Mason et al., 1986) which results in a severe deficiency of pituitary and circulating gonadotrophins. The gonads of the $h p g$ mouse develop, consequently, in an environment free of significant gonadotrophin stimulation. The testes of the hpg mouse remain abdominal throughout life and testicular growth is severely restricted from the perinatal period onwards. The pattern of steroidogenesis in the testis of the hpg adult is unlike that at any age in the normal animal and, presumably, represents basal testicular steroidogenic activity (Sheffield \& O'Shaughnessy, 1988). It is unclear what effect trophic stimulation has on Leydig cell function in the hpg animal. Single daily injections of $h p g$ mice with GnRH stimulate testicular growth and spermatogenesis and multiple daily injections will increase seminal vesicle weight, indicating an increase in serum androgens (Charlton et al., 1983a). In this study we have examined the effect of GnRH injections 
on both the pattern of testicular steroidogenesis and the capacity for androgen synthesis in the $h p g$ mouse.

\section{Materials and Methods}

\section{Materials}

The radioactive steroids $\left[1,2,6,7-{ }^{3} \mathrm{H}\right]$ testosterone, $\left[1,2,6,7 \cdot{ }^{3} \mathrm{H}\right]$ androstenedione, $5 \alpha-\left[1,2(\mathrm{n})-{ }^{3} \mathrm{H}\right]$ androstane- $3 \alpha, 17 \beta-$ diol for radioimmunoassay (RIA) and $\left[4,7-{ }^{3} \mathrm{H}\right]$ pregnenolone for metabolism studies were purchased from Amersham International (Amersham, Bucks, UK). [ $\left.{ }^{3} \mathrm{H}\right]$ Pregnenolone was purified by thin-layer chromatography before use. Non-radioactive steroids were purchased from Sigma Chemical Co. (Poole, Dorset, UK) or Steraloids Ltd (Croydon, Surrey, UK). Organic solvents were purchased from BDH (Poole, Dorset, UK); other chemicals and hormones, including GnRH and hCG, were purchased from Sigma Chemical Co.

\section{Animals and treatments}

Adult $h p g$ mice were provided by Dr H. M. Charlton, Department of Human Anatomy, University of Oxford. Normal animals from the same inbred strain were reared in the Royal Veterinary College from breeding stock provided by Dr H. M. Charlton (Sheffield \& O'Shaughnessy, 1988). Animals were maintained at $24^{\circ} \mathrm{C}$ with light-dark cycle of $12 \mathrm{~h}$ light (lights on at 07:00 h). Animals ( 3 per group) were injected s.c. with $\mathrm{GnRH}$, at the appropriate dose, in $0.2 \mathrm{ml}$ saline $(0.9 \% \mathrm{NaCl}, \mathrm{w} / \mathrm{v})$ or with saline alone. In the first set of experiments animals were injected once daily, between 10:00 and $11: 00 \mathrm{~h}$, and were killed $24 \mathrm{~h}$ after the final injection. In another set of experiments animals ( 3 per group) were treated as above or were injected every $2 \mathrm{~h}$ for 5 days and were killed $2 \mathrm{~h}$ after the final injection. Animals were killed by decapitation and blood was collected to measure serum testosterone concentrations by RIA.

\section{Tissue incubations}

Androgen production. Testes were rapidly removed from animals after decapitation. Whole testes were incubated at $32^{\circ} \mathrm{C}$ for $6 \mathrm{~h}$ in $0.5 \mathrm{ml}$ Medium 199 (Gibco, Paisley, Strathclyde, UK) containing Hepes ( $\left.25 \mathrm{mmol} / 1\right), \mathrm{NaHCO}_{3}$ $(350 \mathrm{mg} / \mathrm{l})$ and $0 \cdot 1 \%(\mathrm{w} / \mathrm{v})$ bovine serum albumin, $\mathrm{pH} 7 \cdot 4(\mathrm{M} 199)$. One testis from each animal was incubated under basal conditions while the contralateral testis was stimulated with hCG $(200 \mathrm{~m}$ i.u. $/ \mathrm{ml})$. The tunica of each testis was cut in several places with fine scissors to allow access of medium and hormones to the tissue parenchyma. Testes from normal adult animals were decapsulated before incubation and the incubation volume was increased to $2 \mathrm{ml}$. Medium from each incubation was stored at $-20^{\circ} \mathrm{C}$ until assayed for androgen content by RIA. Tissue content of androgen was not measured in these experiments but preliminary results indicated that more than $75 \%$ of androgens produced are secreted into the medium and that medium content of androgen reflects total androgen production.

Pregnenolone metabolism. Hemitestes were preincubated in $0.5 \mathrm{ml} \mathrm{M} 199$ for $1 \mathrm{~h}$ under basal conditions or in the presence of hCG $(200 \mathrm{~m} \mathrm{i.u} . / \mathrm{ml})$. After the preincubation, $0.5 \mu \mathrm{Ci}\left[{ }^{3} \mathrm{H}\right]$ pregnenolone was added in $15 \mu \mathrm{l}$ dimethyl sulphoxide and the incubation was continued for a further $2 \mathrm{~h}$ (GnRH-treated) or $5 \mathrm{~h}$ (control hpg). These conditions were chosen to limit substrate metabolism to less than $40 \%$ during the period of the incubation (Table 4). Metabolites formed were extracted and separated as previously described (Mannan \& O'Shaughnessy, 1988; Sheffield \& O'Shaughnessy, 1988).

\section{Radioimmunoassays}

The androgen content of the incubation medium was measured by RIA without previous extraction. Serum testosterone concentrations were measured after extraction with diethyl ether using $\left[{ }^{3} \mathrm{H}\right]$ testosterone to monitor recovery. Testosterone was measured by RIA using antiserum purchased from Guildhay Antisera (Surrey, UK). The limit of detection of the assay, measured as the smallest quantity of testosterone which gives rise to a response significantly different from zero, was $100 \mathrm{fmol} / \mathrm{ml}$. The intra- and inter-assay coefficients of variation were 5.9 and $8.3 \%$ respectively. Cross-reactivity with androstenedione and $5 \alpha$-androstane-3 $3 \alpha, 17 \beta$-diol (androstanediol) was $0 \cdot 3$ and $3.9 \%$ respectively. Androstenedione and androstanediol were measured by RIA using antisera provided by $\mathrm{Dr}$ M. Dowsett (Chelsea Hospital for Women, London, UK). The limit of detection of the assay for androstenedione was $125 \mathrm{fmol} / \mathrm{ml}$ and cross-reactivity was $1.1 \%$ for testosterone and $<0.1 \%$ for androstanediol. The intra- and inter-assay coefficients of variation were $\mathbf{9 . 6}$ and $8.3 \%$ respectively. The limit of detection of the assay for androstanediol was $250 \mathrm{fmol} / \mathrm{ml}$ and cross-reactivity was $5.0 \%$ for testosterone and $9.8 \%$ for androstenedione. The intra- and inter-assay coefficients of variation were 10.6 and $16.4 \%$ respectively. Values are presented in this study without correction for crossreactivity. Total androgen production is expressed as the sum of androstenedione, testosterone and androstanediol production as measured by individual RIAs. 


\section{Statistics}

The effects of hCG were analysed by paired $t$ tests. Other effects were analysed by analysis of variance and the Newman-Keul test. Metabolites formed from $\left[{ }^{3} \mathrm{H}\right]$ pregnenolone have been expressed as a percentage of the total $\left[{ }^{3} \mathrm{H}\right]$ pregnenolone metabolized. This removes differences in the total percentage of substrate metabolized due to differences in activity between individual samples.

\section{Results}

\section{Effect of single daily injections of GnRH}

Daily injections of all doses of GnRH caused an increase in testicular weight (Table 1). The changes in testicular weight were both time- and dose-dependent with the maximum increase observed using $1 \mu \mathrm{g} \mathrm{GnRH}$ for 20 days. No significant changes in seminal vesicle weight were observed at any time and serum testosterone concentrations remained undetectable throughout. In control hpg mice synthesis of $\mathrm{C}_{19}$ steroids in vitro was very low (in some cases undetectable) and was not enhanced by the addition of hCG (Table 2). All doses of GnRH treatment increased both basal and hCG-stimulated androgen production in vitro. After 5 days of treatment with GnRH, androstenedione and androstanediol were the major androgens produced under basal conditions and after hCG stimulation (Table 2). By 10 days the concentrations of all three $\mathrm{C}_{19}$ steroids were similar at each dose of $\mathrm{GnRH}$ tested except for basal androstanediol production which was undetectable after treatment with $50 \mathrm{ng} /$ day. After 20 days treatment, androstenedione production had declined markedly while testosterone synthesis was high after treatment with $50 \mathrm{ng} / \mathrm{day}$. Androstanediol and testosterone production were similar after treatment with $10 \mathrm{ng}$ or $1000 \mathrm{ng} /$ day for 20 days. In normal adult animals testosterone was the major androgen produced by the testes in vitro with markedly lower production of androstenedione and androstanediol (Table 2).

Table 1. Effect of GnRH treatment on testicular weight in hpg males

\begin{tabular}{|c|c|c|c|}
\hline $\begin{array}{l}\text { Time } \\
\text { (days) }\end{array}$ & $\underset{(\mathrm{ng})}{\mathrm{GnRH}}$ & $\begin{array}{l}\text { Testis weight } \\
(\mathrm{mg})(\mathrm{N}=3)^{*}\end{array}$ & $\begin{array}{l}\text { Body weight } \\
\text { (g) }(\mathrm{N}=3)^{*}\end{array}$ \\
\hline 0 & 0 & $1 \cdot 6 \pm 0 \cdot 3$ & $25 \cdot 3 \pm 1 \cdot 2$ \\
\hline 20 & 0 & $2 \cdot 1 \pm 0.7$ & $29 \cdot 3 \pm 0.8$ \\
\hline 5 & $\begin{array}{r}10 \\
50 \\
1000\end{array}$ & $\begin{array}{l}2.2 \pm 0.3 \\
3.5 \pm 0.5 \\
3.8 \pm 0.4\end{array}$ & $\begin{array}{l}23.8 \pm 1.9 \\
26.0 \pm 0.8 \\
23.0 \pm 0.9\end{array}$ \\
\hline 10 & $\begin{array}{r}10 \\
50 \\
1000\end{array}$ & $\begin{array}{l}4.2 \pm 0.7 \\
7.2 \pm 0.2 \\
6.2 \pm 0.4\end{array}$ & $\begin{array}{l}24.1 \pm 0.4 \\
26.9 \pm 1.2 \\
21.4 \pm 1.0\end{array}$ \\
\hline 20 & $\begin{array}{r}10 \\
50 \\
1000\end{array}$ & $\begin{array}{r}7.9 \pm 0.6 \\
12.0 \pm 0.8 \\
12.9 \pm 1.1\end{array}$ & $\begin{array}{l}24 \cdot 8 \pm 1 \cdot 6 \\
24 \cdot 2 \pm 1 \cdot 0 \\
25 \cdot 6 \pm 1 \cdot 1\end{array}$ \\
\hline
\end{tabular}

Values are mean \pm s.e.m.

*In the normal 60 -day-old animal testicular weight is $107 \pm 3 \mathrm{mg}$ and bodyweight is $33 \pm 2 \mathrm{~g}(\mathrm{~N}=6)$.

Total androgen production after GnRH treatment for up to 20 days is shown in Table 3. At all times after GnRH treatment the testes were sensitive to hCG stimulation in vitro. After 5 days the total androgen production was similar at all 3 doses of GnRH tested. Between 5 and 10 days there was a decline in hCG-stimulated androgen production at all doses of GnRH. At the lowest dose of $\mathrm{GnRH}$ ( $10 \mathrm{ng} /$ day) this decline in androgen production continued up to 20 days. In contrast, there 
Table 2. Androgen production in vitro by whole testes from $h p g$ mice after daily GnRH injections

\begin{tabular}{|c|c|c|c|c|c|c|c|}
\hline \multirow{3}{*}{$\begin{array}{l}\text { Time } \\
\text { (days) }\end{array}$} & \multirow{3}{*}{$\begin{array}{c}\text { GnRH } \\
\text { (ng) }\end{array}$} & \multicolumn{6}{|c|}{ Steroid production (pmol/testis) } \\
\hline & & \multicolumn{2}{|c|}{ Androstenedione } & \multicolumn{2}{|c|}{ Testosterone } & \multicolumn{2}{|c|}{ Androstenediol } \\
\hline & & Basal & $\mathrm{hCG}$ & Basal & hCG & Basal & hCG \\
\hline $0^{*}$ & 0 & $0 \cdot 20 \pm 0.10$ & $0.21 \pm 0.09$ & $0.21 \pm 0.10$ & $0.19 \pm 0.06$ & ND & $0.18 \pm 0.09$ \\
\hline 20 & 0 & $0 \cdot 25 \pm 0.07$ & $0 \cdot 18 \pm 0 \cdot 04$ & $0.14 \pm 0.05$ & $0.21 \pm 0.06$ & $0.15 \pm 0.04$ & $0 \cdot 27 \pm 0 \cdot 10$ \\
\hline 5 & $\begin{array}{r}10 \\
50 \\
1000\end{array}$ & $\begin{array}{l}3.68 \pm 0.99 \\
2.50 \pm 0.71 \\
2.42 \pm 0.93\end{array}$ & $\begin{array}{l}10.8 \pm 3.79 \\
8.13 \pm 4.85 \\
8.67 \pm 2.72\end{array}$ & $\begin{array}{l}0.87 \pm 0.12 \\
1.64 \pm 0.31 \\
1.78 \pm 0.16\end{array}$ & $\begin{array}{l}4.30 \pm 1.45 \\
2.58 \pm 1.07 \\
2.98 \pm 0.79\end{array}$ & $\begin{array}{l}1.33 \pm 0.78 \\
1.93 \pm 0.68 \\
4.47 \pm 1.20\end{array}$ & $\begin{array}{l}7 \cdot 11 \pm 2.83 \\
9.62 \pm 3.93 \\
8.87 \pm 3.05\end{array}$ \\
\hline 10 & $\begin{array}{r}10 \\
50 \\
1000\end{array}$ & $\begin{array}{l}1.88 \pm 0.40 \\
2.98 \pm 1.44 \\
1 \cdot 73 \pm 0.15\end{array}$ & $\begin{array}{l}5.37 \pm 1.29 \\
4.45 \pm 0.77 \\
4.18 \pm 1.48\end{array}$ & $\begin{array}{l}2.41 \pm 0.33 \\
1.16 \pm 0.67 \\
0.98 \pm 0.41\end{array}$ & $\begin{array}{l}2.76 \pm 0.14 \\
7.31 \pm 1.06 \\
3.51 \pm 1.51\end{array}$ & $\begin{array}{c}2.00 \pm 0.88 \\
\mathrm{ND} \\
0.71 \pm 0.35\end{array}$ & $\begin{array}{l}2.95 \pm 0.50 \\
3.01 \pm 0.92 \\
3.52 \pm 1.21\end{array}$ \\
\hline 20 & $\begin{array}{r}10 \\
50 \\
1000\end{array}$ & $\begin{array}{l}0.16 \pm 0.08 \\
0.21 \pm 0.04 \\
0.11 \pm 0.04\end{array}$ & $\begin{array}{c}0.23 \pm 0.05 \\
\mathrm{ND} \\
0.51 \pm 0.09\end{array}$ & $\begin{array}{l}3.97 \pm 1.38 \\
6.61 \pm 0.93 \\
4.26 \pm 1.05\end{array}$ & $\begin{array}{l}2.93 \pm 1.58 \\
40.8 \pm 7.63 \\
9.14 \pm 1.32\end{array}$ & $\begin{array}{l}0.77 \pm 0.14 \\
2.80 \pm 0.83 \\
4.30 \pm 1.80\end{array}$ & $\begin{array}{l}4 \cdot 02 \pm 1 \cdot 03 \\
4 \cdot 33 \pm 0 \cdot 12 \\
8 \cdot 07 \pm 2 \cdot 23\end{array}$ \\
\hline Norma & lult males & $32 \pm 4$ & $252 \pm 40$ & $239 \pm 48$ & $1568 \pm 140$ & $17 \pm 4$ & $111 \pm 25$ \\
\hline
\end{tabular}

Values are mean \pm s.e.m. for 3 males/group.

ND, not detectable.

*This group contained 5 animals and androgen production was undetectable in 2: the values reported are for the remaining 3 animals.

Table 3. Total androgen production by testes from $h p g$ mice after daily $\mathrm{GnRH}$ injections

\begin{tabular}{|c|c|c|c|}
\hline \multirow{2}{*}{$\begin{array}{l}\text { Time } \\
\text { (days) }\end{array}$} & \multirow{2}{*}{$\begin{array}{c}\text { GnRH } \\
\text { (ng) }\end{array}$} & \multicolumn{2}{|c|}{$\begin{array}{l}\text { Total androgen production } \\
\text { (pmol/testis) }\end{array}$} \\
\hline & & Basal & hCG-stimulated \\
\hline 0 & 0 & $0.41 \pm 0.15$ & $0.58 \pm 0.20$ \\
\hline 20 & 0 & $0.54 \pm 0.19$ & $0.66 \pm 0.24$ \\
\hline 5 & $\begin{array}{r}10 \\
50 \\
1000\end{array}$ & $\begin{array}{l}5.88 \pm 1.82^{\mathrm{a}} \\
6.07 \pm 1.71^{\mathrm{a}} \\
8.67 \pm 2.20^{\mathrm{a}}\end{array}$ & $\begin{array}{l}22 \cdot 2 \pm 6.44^{a} \\
20 \cdot 3 \pm 9 \cdot 87^{a} \\
20 \cdot 5 \pm 5 \cdot 61^{a}\end{array}$ \\
\hline 10 & $\begin{array}{r}10 \\
50 \\
1000\end{array}$ & $\begin{array}{l}6 \cdot 29 \pm 1 \cdot 32^{\mathrm{a}} \\
4.14 \pm 1 \cdot 52^{\mathrm{a}} \\
3.42 \pm 1 \cdot 23^{\mathrm{a}}\end{array}$ & $\begin{array}{l}11 \cdot 1 \pm 3 \cdot 12^{\mathrm{a}} \\
14 \cdot 8 \pm 2 \cdot 52^{\mathrm{a}} \\
11 \cdot 2 \pm 0.53^{\mathrm{a}}\end{array}$ \\
\hline 20 & $\begin{array}{r}10 \\
50 \\
1000\end{array}$ & $\begin{array}{l}4.93 \pm 1 \cdot 44^{\mathrm{a}} \\
9.62 \pm 2 \cdot 00^{\mathrm{a}} \\
8.67 \pm 2 \cdot 71^{\mathrm{a}}\end{array}$ & $\begin{array}{r}7 \cdot 2 \pm 2 \cdot 94^{\mathrm{a}} \\
45 \cdot 1 \pm 11 \cdot 8^{\mathrm{b}} \\
17 \cdot 7 \pm 1 \cdot 10^{\mathrm{a}}\end{array}$ \\
\hline Norma & dult male & $288 \pm 40$ & $1931 \pm 130$ \\
\hline
\end{tabular}

Values are mean \pm s.e.m. for 3 animals per group.

Within a single time point and treatment regimen in vitro, values with different superscripts are significantly $(P<0.05)$ different. The effects of hCG in vitro were significant as asssessed by paired $t$ tests at each time of GnRH treatment.

was an increase in androgen production between 10 and 20 days following treatment with 50 and $1000 \mathrm{ng} /$ day although the effect of $50 \mathrm{ng} /$ day was significantly greater. Androgen production in $h p g$ male animals treated with GnRH, although greater than in controls, remained markedly lower than in normal adult animals (Table 3). 
Table 4. $\left[{ }^{3} \mathrm{H}\right]$ Pregnenolone metabolism after $\mathrm{GnRH}$ treatment $(50 \mathrm{ng} / \mathrm{day})$ of $h p g$ mice for 5 days

\begin{tabular}{|c|c|c|c|c|}
\hline \multirow[b]{3}{*}{ Metabolite* } & \multicolumn{4}{|c|}{ Steroid formed (\% of $\left[{ }^{3} \mathrm{H}\right]$ pregnenolone metabolized) } \\
\hline & \multicolumn{2}{|c|}{ Control animals } & \multicolumn{2}{|c|}{ GnRH-treated animals } \\
\hline & Basal & hCG-stimulated $\dagger$ & Basal & hCG-stimulated $\dagger$ \\
\hline $170 \mathrm{HP}_{5}$ & $12 \cdot 0 \pm 7 \cdot 5$ & $7 \cdot 1 \pm 0 \cdot 7$ & ND & ND \\
\hline Progesterone & $38.7 \pm 9.9$ & $52.3 \pm 5.7$ & $25.0 \pm 4.6$ & $21 \cdot 3 \pm 6 \cdot 5$ \\
\hline $170 \mathrm{HP}_{4}$ & $4.9 \pm 0.4$ & $5 \cdot 1 \pm 1 \cdot 4$ & $3.4 \pm 0.2$ & $3.7 \pm 0.6$ \\
\hline Androstenedione & $13.4 \pm 3.8$ & $10 \cdot 3 \pm 1 \cdot 1$ & $31 \cdot 3 \pm 5 \cdot 5$ & $17.0 \pm 4.9$ \\
\hline Testosterone & $1 \cdot 1 \pm 0 \cdot 1$ & $1.4 \pm 0.2$ & $29 \cdot 9 \pm 3 \cdot 1$ & $24 \cdot 3 \pm 4 \cdot 3$ \\
\hline Androstanediol & $4 \cdot 7 \pm 1 \cdot 1$ & $5.8 \pm 1 \cdot 2$ & $7 \cdot 7 \pm 4.5$ & $17 \cdot 7 \pm 7 \cdot 7$ \\
\hline Androsterone & $0.4 \pm 0.3$ & $1.5 \pm 0.1$ & $3.4 \pm 2.7$ & $1.1 \pm 0.6$ \\
\hline $5 \alpha \mathrm{DHP}_{4}$ & $6.7 \pm 1.6$ & $2.5 \pm 1.0$ & ND & ND \\
\hline Allopregnenolone & $2.7 \pm 2.2$ & $0.4 \pm 0.3$ & $0.8 \pm 0.7$ & $3 \cdot 2 \pm 2 \cdot 5$ \\
\hline Unidentified 1 & $\mathrm{ND}$ & $\mathrm{ND}$ & $\mathrm{ND}$ & $11.4 \pm 7.3$ \\
\hline 2 & $11 \cdot 9 \pm 4 \cdot 1$ & $7.4 \pm 1.9$ & ND & ND \\
\hline \multirow[t]{2}{*}{$\begin{array}{l}\text { Pregnenolone } \\
\text { metabolized } \ddagger\end{array}$} & $33 \cdot 3+3 \cdot 5$ & $29 \cdot 8+4 \cdot 6$ & $24 \cdot 0+4 \cdot 2$ & $24 \cdot 2+5 \cdot 2$ \\
\hline & $33.3 \pm 3.5$ & $29 \cdot 8 \pm 4 \cdot 6$ & $24 \cdot 0 \pm 4 \cdot 2$ & $24 \cdot 2 \pm 5 \cdot 2$ \\
\hline
\end{tabular}

Results are mean \pm s.e.m. of tissue from 3 animals per group.

ND, not detectable.

*Only those metabolites which made up more than $3 \%$ of $\left[{ }^{3} \mathrm{H}\right]$ pregnenolone metabolized in at least one group are shown. $170 \mathrm{HP}_{5}, 17 \alpha$-hydroxypregnenolone; $170 \mathrm{HP}_{4}, 17 \alpha$-hydroxyprogesterone; $5 \alpha \mathrm{DHP}_{4}, 5 \alpha$-dihydroprogesterone.

$\dagger 200$ mi.u./ml.

†Percentage of added $\left[{ }^{3} \mathrm{H}\right]$ pregnenolone metabolized in each group.

The pattern of $\left[{ }^{3} \mathrm{H}\right]$ pregnenolone metabolism by testes from mice injected with $50 \mathrm{ng} /$ day for 5 days is shown in Table 4. In control hpg mice progesterone was the major metabolite formed from exogenous pregnenolone as previously described (Sheffield \& O'Shaughnessy, 1988). After GnRH treatment there was a marked increase in metabolism beyond progesterone to the $C_{19}$ steroids. Metabolism of pregnenolone was almost exclusively via the 4-ene pathway with significant formation of the $5 \alpha$-reduced steroids androsterone, allopregnenolone and androstanediol, confirming the presence of high $5 \alpha$-reductase. Acute stimulation with hCG had no significant effect on the pattern of pregnenolone metabolism in control hpg animals but caused a significant increase in the percentage conversion to androstanediol in GnRH-treated animals.

\section{Effect of multiple daily injections of $\mathrm{GnRH}$}

The effect of 12 injections daily with $4.2 \mathrm{ng} \mathrm{GnRH}$ (total daily dose $50 \mathrm{ng}$ ) were compared with single injections daily of $50 \mathrm{ng}$ GnRH. Neither treatment affected seminal vesicle weights and serum testosterone remained undetectable. The effects of single and multiple daily injections of GnRH on total androgen production in vitro are shown in Fig. 1. Both basal and hCG-stimulated androgen production were greater after multiple injections of $\mathrm{GnRH}$ than single daily injections but this difference was not significant $(P>0.05)$. In this experiment addition of hCG in vitro caused a significant $(P<0.05)$ increase in androgen production by testes from control animals although the level of androgen synthesis was markedly lower than in GnRH-treated animals.

\section{Discussion}

It is clear from these experiments that GnRH treatment of $h p g$ mice causes a marked and rapid increase in testicular androgen production. This enhanced steroidogenesis probably helps to 


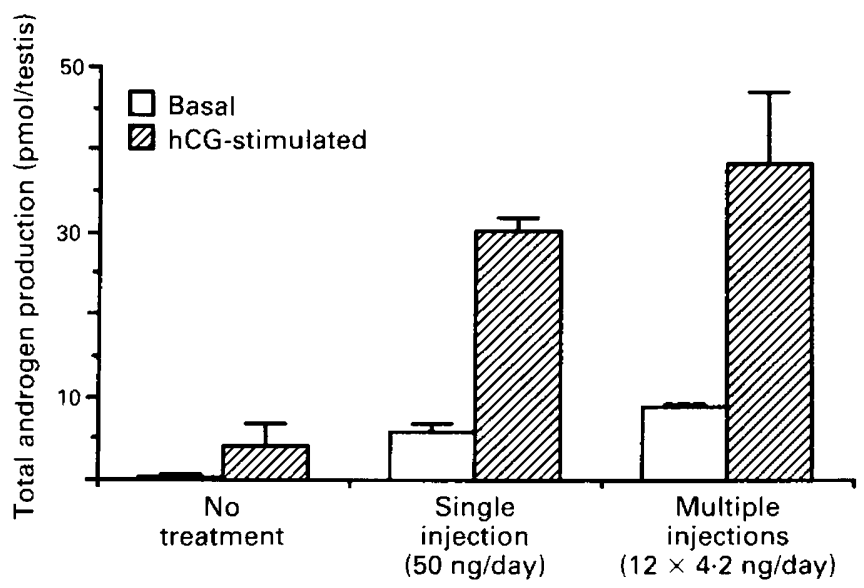

Fig. 1. Effect of single or multiple daily injections of GnRH on total androgen production by testes from hpg mice. Animals were injected once daily with $50 \mathrm{ng} \mathrm{GnRH}$ or 12 times daily with $4.2 \mathrm{ng}$ GnRH or saline. After 5 days treatment androgen production was measured in vitro. Results from 3 separate animals in each group are shown as mean \pm s.e.m.

stimulate development of the seminiferous tubules and testicular growth although blood androgen concentrations are clearly not increased to a level which affects seminal vesicle weights. Charlton et al. (1983a) have shown that the treatments used in this study will cause a marked increase in pituitary FSH content but that they have little or no effect on pituitary LH. Injection of GnRH to hpg mice does, however, cause a rapid transient increase in plasma LH and FSH values and testes in treated animals would, therefore, be exposed to elevated concentrations of both gonadotrophins. It is unlikely that any of the effects observed here are due to direct actions of GnRH on the testis since mouse Leydig cells have been shown to be insensitive to this hormone (Hunter et al., 1982).

Testes from GnRH-treated $h p g$ mice contained high levels of $5 \alpha$-reductase, particularly during the first 5 days of treatment, if compared to the normal adult animal (Sheffield \& O'Shaughnessy, 1988). High levels of enzyme activity occurred in the metabolism of $\left[{ }^{3} \mathrm{H}\right]$ pregnenolone to $5 \alpha$ reduced steroids, particularly in the presence of hCG, and in the high output of androstanediol, as measured by RIA. It is likely that this high level of activity is due to induction of enzyme synthesis by the GnRH treatment although there appear to be significant amounts of $5 \alpha$-reductase in testes of control hpg mice. During development in the normal mouse $5 \alpha$-reductase activity starts to show a marked increase between 15 and 20 days and then declines again by about 35 days (Tsujimura $\&$ Matsumoto, 1974; Chase \& Payne, 1983; Sheffield \& O'Shaughnessy, 1988). During this time there is also a significant increase in Leydig cell androgen production (Chase \& Payne, 1983). Treatment of adult $h p g$ mice with GnRH therefore appears to stimulate changes in testicular function similar to those which occur during normal development. In addition, androgen production in hpg testes, after GnRH treatment, was almost entirely via the 4-ene pathway which resembles the immature normal mouse (15-25 days) but is in contrast to the adult animal (Sheffield \& O'Shaughnessy, 1988). The total androgen production in GnRH-treated hpg animals remained markedly lower than in normal adult animals. This is similar to the 20 - and 30 -day-old mouse which produces only $1-2 \%$ of the adult level of androgen per testis (Anakwe \& Moger, 1984). The amount of androgen produced per testis after GnRH treatment of $h p g$ mice is very similar to that in the normal 20-day-old animal reported by Anakwe \& Moger (1984).

There is strong evidence that $5 \alpha$-reductase activity in the immature rat is regulated by LH (Nayfeh et al., 1975; Murono \& Payne, 1979; Chase \& Payne, 1985) and that prolactin can augment the effect of LH (Chase \& Payne, 1985; Takeyama et al., 1986). The pituitary content of prolactin is 
normal in adult hpg males (Charlton $e$ t al., 1983b) and high levels of activitiy of $5 \alpha$-reductase in the $h p g$ testis following GnRH treatment may reflect, therefore, increased stimulation by LH. Leydig cells which develop after ethylene dimethanesulphonate treatment of adult rats also go through a transient period in which $5 \alpha$-reductase activity is high (Vreeburg et al., 1988). It is possible, therefore, that once Leydig cell development is stimulated an early event is expression of high levels of $5 \alpha$-reductase, provided the hormonal environment is suitable.

In this study the concentration of $\left[{ }^{3} \mathrm{H}\right]$ pregnenolone used as substrate to measure the pattern of steroidogenesis was not limiting. The marked change in the pattern of $\left[{ }^{3} \mathrm{H}\right]$ pregnenolone metabolism following GnRH treatment suggests, therefore, that the effects observed are due, at least partly, to changes in Leydig cell activity rather than solely a change in cell number per testis. The increase in progesterone metabolism, after $\mathrm{GnRH}$, suggests that $17 \alpha$-hydroxylase $/ \mathrm{C}_{17}-\mathrm{C}_{20}$ lyase activity is increased per cell. This would be consistent with the results of Purvis et al. (1973), O'Shaughnessy \& Payne (1982) and Anakwe \& Payne (1987) which have shown that this enzyme is under gonadotrophin regulation. The marked increase in androgen production which occurs in the testes of hpg mice after GnRH treatment suggests that changes in the activity of other steroidogenic enzymes have occurred. Activity of both $3 \beta$-hydroxysteroid dehydrogenase and cholesterol sidechain cleavage has also been shown to be under gonadotrophin regulation (Murono \& Payne, 1979; O'Shaughnessy \& Payne, 1982; Funkenstein et al., 1983; Anakwe \& Payne, 1987). Activity of 17ketosteroid reductase appears to be less sensitive to gonadotrophin regulation (Murono \& Payne, 1979; O'Shaughnessy \& Payne, 1982) which may explain why relatively high concentrations of androstenedione were produced after 5 and 10 days' treatment.

The pituitary-testicular axis in adult hpg males appears to be very sensitive to GnRH since all three doses caused the same marked increase in steroidogenesis during the first 5 days. Similarly, hCG-stimulated androgen secretion declined at all doses of GnRH between 5 and 10 days of treatment. The reason for this decrease is not clear but may be due to desensitization to GnRH at the pituitary or to the gonadotrophins at the testis. Large doses of $\mathrm{GnRH}$ are known to cause pituitary desensitization with a subsequent decrease in gonadotrophin secretion (Haynes et al., 1977; de Konig et al., 1978; Fraser \& Lincoln, 1980). Similarly, testicular responsiveness to both LH and FSH can be desensitized by exposure to elevated concentrations of the hormone (Sharpe, 1977; O'Shaughnessy, 1980; Quinn \& Payne, 1985). Alternatively, the decline in responsiveness to the lowest dose of GnRH may be due to the inability of this concentration of GnRH to sustain pituitary function after the initial surge in activity. With higher doses of GnRH there was an increase in steroidogenic activity between 10 and 20 days, the effect being significantly greater at $50 \mathrm{ng} /$ day than $1000 \mathrm{ng} /$ day. There was no difference in testicular weight after 20 days' treatment with 50 or $1000 \mathrm{ng} /$ day which suggests that, while androgen production is lower after $1000 \mathrm{ng} / \mathrm{day}$, perhaps due to tissue desensitization, it is sufficient to maintain testicular growth.

Gonadotrophins are known to be released from the pituitary in a pulsatile manner and this reflects secretion of GnRH from the hypothalamus (Clarke \& Cummins, 1982; Levine et al., 1982). The episodic pattern of $\mathbf{L H}$ secretion is important for events such as initiation of puberty (Foster et al., 1978) and control of the oestrous cycle (Marut et al., 1981). Little is known, however, about the effect of changing GnRH pulse-frequency on the pituitary-gonadal axis in the male. The importance of pulsatile secretion of LH to Leydig cell function is uncertain, there is little difference in responsiveness of perfused cultured Leydig cells to constant exposure to $\mathrm{LH}$ or pulsatile exposure (Verhoeven et al., 1986). In addition Chase et al. (1988) have shown that a pulsatile pattern of LH secretion in rams is not necessary for its trophic actions. In the present study there was no significant difference between treating $h p g$ animals once daily or 12 times daily. It is unlikely that the dose used during multiple injections $(4 \cdot 2 \mathrm{ng})$ is too low to affect the pituitary since $10 \mathrm{ng}$ was as effective as $50 \mathrm{ng}$ and $1000 \mathrm{ng}$ in stimulating steroidogenesis during the first 5 days of treatment. The lack of effect of multiple injections may be due to artefacts of the system used, such as frequency of injection or doses of GnRH used, or it is possible that a pulsatile pattern of GnRH may be unimportant in stimulating testicular function. 
This study was supported by a grant from the MRC. We thank Dr H. M. Charlton for providing hpg animals and Dr M. Dowsett for providing antisera.

\section{References}

Anakwe, O.O. \& Moger, W.H. (1984) Ontogeny of rodent testicular androgen production in response to isoproterenol and luteinising hormone in vitro. Biol. Reprod. 30, 1142-1152.

Anakwe, O.O. \& Payne, A.H. (1987) Noncoordinate regulation of the de novo synthesis of cytochrome $P$ 450 cholesterol side-chain cleavage and cytochrome $\mathrm{P}-450$ 17a-hydroxylase/C17-20 lyase in mouse leydig cells: relation to steroid production. Molec. Endocr. $1,595-603$.

Charlton, H.M., Halpin, D.M.G., Iddon, C., Rosie, R., Levy, G., McDowell, I.F.W., Megson, A., Morris, J.F., Bramwell, A., Speight, A., Ward, B.J., Broadhead, J., Davey-Smith, G. \& Fink, G. (1983a) The effects of daily administration of single and multiple injections of gonadotropin-releasing hormone on pituitary and gonadal function in the hypogonadal ( $h p g$ ) mouse. Endocrinology 113, 535-544.

Charlton, H.M., Speight, A., Halpin, D.M.G., Bramwell, A., Sheward, W.J. \& Fink, G. (1983b) Prolactin measurements in normal and hypogonadal (hpg) mice: developmental and experimental studies. Endocrinology 113, 545-548.

Chase, D.J. \& Payne, A.H. (1983) Changes in Leydig cell function during sexual maturation in the mouse. Biol. Reprod. 29, 1194-1200.

Chase, D.J. \& Payne, A.H. (1985) Prolactin involvement in regulation of testicular $5 \alpha$-reductase activity in the immature rat. Biol. Reprod. 33, 637-643.

Chase, D.J., Schanbacher, B.D. \& Lunstra, D.D. (1988) Effects of pulsatile and continuous luteinizing hormone ( $\mathrm{LH})$ infusions on testosterone responses to $\mathrm{LH}$ in rams actively immunized against gonadotrophin-releasing hormone. Endocrinology 123, 816-826.

Clarke, I.J. \& Cummins, J.T. (1982) The temporal relationship between gonadotrophin-releasing hormone (GnRH) and luteinizing hormone (LH) secretion in ovariectomized ewes. Endocrinology 111, 1737-1739.

de Konig, J., van Dieten, J.A.M.J. \& van Rees G.P. (1978) Refractoriness of the pituitary gland after continuous exposure to luteinising hormone-releasing hormone. J. Endocr. 79, 311-318.

Foster, D.L., Mickelson, I.H., Ryan, K.D., Coon, G.A., Drongowski, R.A. \& Holt, J.A. (1978) Ontogeny of pulsatile luteinising hormone and testosterone secretion in male lambs. Endocrinology 102, 1137-1146.

Fraser, H.M. \& Lincoln, G.A. (1980) Effects of chronic treatment with an LHRH agonist on the secretion of LH, FSH and testosterone in the ram. Biol. Reprod. 22, 269-276.

Funkenstein, B., Waterman, M.R., Masters, B.S.S. \& Simpson, E.R. (1983) Evidence for the presence of cholesterol side-chain cleavage cytochrome P-450 and adrenodoxin in fresh granulosa cells. Effects of folliclestimulating hormone and cyclic AMP on cholesterol side-chain cleavage cytochrome $\mathrm{P}-450$ synthesis and activity. J. biol. Chem. 258, 10187-10191.

Haynes, N.B., Hafs, H.D. \& Manns, J.G. (1977) Effect of chronic administration of gonadotrophin releasing hormone to pubertal bulls on plasma luteinising hormone, prolactin and testosterone concentrations, the number of epididymal sperm and body weight. $J$. Endocr. 73, 227-234.

Hunter, M.G., Sullivan, M.H.F., Dix, C.J., Aldred, L.F. \& Cooke, B.A. (1982) Stimulation and inhibition by LHRH analogues of cultured rat Leydig cell function and lack of effect on mouse Leydig cells. Molec. cell. Endocr. 27, 31-44.

Levine, J.E., Paul, K-Y.F., Ramirez, V.D. \& Jackson, F.L. (1982) Simultaneous measurements of luteinizing hormone-releasing hormone and luteinizing hormone release in unanesthetized ovariectomized sheep. Endocrinology 111, 1449-1455.

Mannan, M.A. \& O'Shaughnessy, P.J. (1988) Ovarian steroid metabolism during post-natal development in the normal mouse and in the adult hypogonadal (hpg) mouse. J. Reprod. Fert. 82, 727-734.

Marut, E.L., Williams, R.F., Cowan, B.D., Lynch, A., Lerner, S.P. \& Hodgen, G.D. (1981) Pulsatile pituitary gonadotrophin secretion during maturation of the dominant follicle in monkeys: estrogen positive feedback enhances the biological activity of LH. Endocrinology 109, 2270-2272.

Mason, A.J., Hayflick, J.S., Zoeller, R.T., Young, W.S., Phillips, H.S., Nikolics, K. \& Seeburg, T.A. (1986) A deletion truncating the GnRH gene is responsible for hypogonadism in the hpg mouse. Science, $N Y 234$, 1366-1371.

Murono, E.P. \& Payne, A.H. (1979) Testicular maturation in the rat. In vivo effect of gonadotrophins on steroidogenic enzymes in the hypophysectomised immature rat. Biol. Reprod. 20, $911-917$.

Nayfeh, S.N., Coffey, J.C., Hansson, V. \& French, F.S. (1975) Maturational changes in testicular steroidogenesis: hormonal regulation of 5-reductase. J. Steroid Biochem. 6, 329-335.

O'Shaughnessy, P.J. (1980) FSH receptor autoregulation and cyclic AMP production in the immature rat testis. Biol. Reprod. 23, 810-814.

O'Shaughnessy, P.J. \& Payne, A.H. (1982) Differential effects of single and repeated administration of gonadotrophin on testosterone production and steroidogenic enzymes in Leydig cells. J. biol. Chem. 257, 11503-11509.

Purvis, J.L., Canick, J.A., Latif, S.A., Rosenbaum, J.H., Hologittas, J. \& Menard, R.H. (1973) Control of cytochrome $\mathbf{P}-450$ in rat testis mitochondria by human chorionic gonadotrophin. Archs Biochem. Biophys. 159, 32-38.

Quinn, P.G. \& Payne, A.H. (1985) Steroid productinduced, oxygen-mediated damage of microsomal cytochrome P-450 enzymes in Leydig cell cultures. 
Relationship to desensitization. J. biol. Chem. 260, 2092-2099.

Sharpe, R.M. (1977) Gonadotrophin-induced reduction in the steroidogenic responsiveness of the immature rat testis. Biochem. Biophys. Res. Commun. 76, 957-962.

Sheffield, J.W. \& O'Shaughnessy, P.J. (1988) Testicular steroid metabolism during development in the normal and hypogonadal mouse. J. Endocr. 119, 257-264.

Takeyama, M., Nagareda, T., Takatsuka, D., Namiki, M., Koizumi, K., Aono, T. \& Matsumoto, K. (1986) Stimulatory effect of prolactin on luteinizing hormoneinduced testicular $5 \alpha$-reductase activity in hypophysectomized adult rats. Endocrinology 118, 2268-2275.
Tsujimura, T. \& Matsumoto, K. (1974) Progesterone metabolism in vitro by mouse testes at different stages of development. Endocrinology 94, 288-290.

Verhoeven, G., Cailleau, J., van der Shueren, B. \& Cassiman, J.-J. (1986) The dynamics of steroid and adenosine $3^{\prime}, 5^{\prime}$-cyclic monophosphate output in perifused interstitial cell aggregates derived from prepubertal rat testes. Endocrinology 119, 1476-1488.

Vreeburg, J.T.M., Ooms, M.P., Rommerts, F.F.G. \& Teerds, K.J. (1988) Functional properties of developing rat Leydig cells after treatment with ethylene dimethanesulphonate (EDS). J. Reprod. Fert. 84, 63-69.

Received 31 October 1988 